\title{
ANTAGONISTIC AND PROTECTIVE EFFECTS AGAINST SALMONELLA ENTERICA SEROVAR TYPHIMURIUM BY LACTOBACILLUS MURINUS IN THE DIGESTIVE TRACT OF GNOTOBIOTIC MICE
}

\section{Ana Luiza Sampaio Vasconcelos; Jacques Robert Nicoli*; Regina Maria Drummond Nardi}

Departamento de Microbiologia, Instituto de Ciências Biológicas, Universidade Federal de Minas Gerais, Belo Horizonte, MG, Brasil.

\begin{abstract}
This paper corresponds to an "extended abstract" selected for oral presentation in the $22^{\text {nd }}$ Brazilian Congress of Microbiology, held in Florianópolis, SC, Brazil, in November 17-20, 2003
\end{abstract}

\begin{abstract}
In the present study, production of antagonistic substances by Lactobacillus murinus against enteropathogenic bacteria was evaluated in vivo as well as a possible protective effect against an oral challenge with Salmonella Typhimurium using a gnotobiotic animal model. A higher mean survival time $(\mathrm{P}<0.05)$ was observed in L. murinusassociated animals ( $7.89 \pm 3.83$ days) when compared with the control ones (4.44 \pm 0.73 days). Lactobacillus murinus exerted a potent antagonistic effect in vivo against $S$. sonnei and to a lesser extent against $S$. Typhimurium as revealed by inhibitory halos around the feces of Lactobacillus-associated animals. Diameters of inhibitory halos around intestinal contents increased along the intestine tract, following proportionally the L. murinus population levels in the respective intestinal portions. Concluding, the present study showed that L. murinus association in gnotobiotic mice delayed the death after an oral challenge with $S$. Typhimurium and that inhibitory diffusible compounds obtained in in vitro assays were also produced in vivo and may be responsible for this effect.
\end{abstract}

Key-words: antagonism, Salmonella, Lactobacillus, gnotobiotic mice.

\section{INTRODUCTION}

The intestines of non-human primates and other mammals harbor a vast bacterial ecosystem having several beneficial effects on the host (1). Lactobacilli are dominant components of the microbial ecosystems inhabiting all the portions of the gastrointestinal tract of rodents, swine and non-human primates.

The inhibitory effect of lactobacilli on the growth of various pathogenic enterobacteria is well demonstrated, but generally by in vitro experiments. Several hypothesis can explain the protective effect of lactobacilli against infectious microbes such as (i) production of inhibitory substances (lactic acid, bacteriocin) (8); competition for nutrients or receptors (2); and immunomodulation of the host (6).

Nardi et al. (4) have isolated from a rodent fecal microbiota a Lactobacillus murinus showing, in vitro, a very large heteroantagonistic spectrum against enteropathogenic bacteria. This antagonism was due to diffusible inhibitory compounds, which were currently submitted to purification and characterization in our laboratory.

In the present study, production of the antagonistic compounds against enteropathogenic bacteria was evaluated in vivo as well as a possible protective effect against an oral challenge with Salmonella Typhimurium using a gnotobiotic animal model.

\section{MATERIALS AND METHODS}

\section{Bacteria \\ Lactobacillus murinus was identified by sequence data of 16S ribosomal DNA. Shigella sonnei ATCC 11060 and Salmonella enterica serovar Typhimurium (FUNED, Belo}

* Corresponding author. Mailing address: Departamento de Microbiologia, Instituto de Ciências Biológicas. Universidade Federal de Minas Gerais. Caixa Postal 486. 30161-970, Belo Horizonte, MG, Brasil. Tel.: (+5531) 3499-2757. Fax: (+5531) 3499-2730. E-mail: jnicoli@icb.ufmg.br 
Horizonte, Brazil) were used as indicator strains. All the stock cultures of producer and indicator strains were maintained in MRS or BHI medium at $-70^{\circ} \mathrm{C}$ in $15 \%$ glycerol.

\section{Mice}

Germ-free 21 days old Swiss/NIH mice (Taconic, Germantown, USA) of both sexes were used in this study. Germfree animals were housed in flexible plastic isolators (Standard Safety Company, McHenry, USA). Experiments with gnotobiotic mice were carried out in microisolators (UNO Roestvastaal B.V., Zevenar, The Netherlands). Water and commercial autoclavable diet (Nuvital, Curitiba, Brazil) were sterilized by steam and administered ad libitum. All experimental procedures were carried out according to the standards set forth in the "Guide for the Care and Use of Laboratory Animals" of the National Research Council (5).

\section{Monoassociation with Lactobacillus murinus}

A dose of $0.1 \mathrm{ml}$ containing about $10^{8}$ colony forming units (cfu)/ml of L. murinus was administrated by gavages to each mouse (experimental group, $\mathrm{n}=10$ ), 10 days before the challenge with $S$. Typhimurium. Control group $(\mathrm{n}=10)$ was treated with sterile saline, according to the same schedule as the experimental group.

\section{Experimental infections}

Salmonella Typhimurium was grown in $\mathrm{BHI}$ medium at $37^{\circ} \mathrm{C}$. Each mouse was orally challenged with $0.1 \mathrm{ml}$ of bacterial suspension containing $10^{3} \mathrm{cfu}$ dose was used. Survival of mice was monitored until the $28^{\text {th }}$ day after challenge with $S$. Typhimurium.

\section{Bacterial counts and ex vivo antagonism assays}

Ten days after association of germfree mice with $L$. murinus, the animals were sacrificed by ether inhalation, and contents from various portions of the intestinal tracts were aseptically collected and weighted. Parts of the contents were used for determination of colony forming units/g by decimal serial dilutions and incubation at $37^{\circ} \mathrm{C}$ of $0.1 \mathrm{ml}$ of adequate dilutions onto MRS agar. Approximately $100 \mathrm{mg}$ of intestinal contents and feces were also placed onto Petri dishes containing MRS agar and incubated for $24 \mathrm{~h}$ at $4^{\circ} \mathrm{C}$. After the incubation, this contends were treated with chloroform vapor. Residual chloroform was allowed to evaporate and the Petri dish was overlayed with BHI soft agar $(0.75 \%)$ which had been inoculated with $10^{6} \mathrm{cfu}$ of the indicator strain $(S$. sonnei or $S$. Typhimurium) and incubated at $37^{\circ} \mathrm{C}$ for $18 \mathrm{~h}$. The plates were then checked for the presence of an inhibitory halo around the feces and intestinal contents. The diameter of the inhibitory zone was determined with a digital pachymeter (Mitutoyo, São Paulo, Brazil). Feces from germfree mice were used as the control.

\section{RESULTS AND DISCUSSION}

Fig. 1 shows that all the animals in experimental and control gnotobiotic groups infected with $S$. Typhimurium died. However, a higher mean survival time $(\mathrm{P}<0.05)$ was observed in L. murinusassociated animals ( $7.89 \pm 3.83$ days) when compared with the control ones ( $4.44 \pm 0.73$ days). This experiment shows that $L$. murinus was not capable of completely protecting the mice against the enteropathogenic bacteria when the normal microbiota was absent, but contribute to delay the death.

The production of antimicrobial substances is one of the most cited in the literature as responsible for antagonistic and protective effects in various ecosystems. However, the presence of these antimicrobial compounds has been demonstrated generally in vitro, and it is unclear whether they are produced or have activity in vivo. As an example, opposite data have been obtained in in vitro and in vivo experiments in which bacteriocin-sensitive Escherichia coli strains were found to inhibit bacteriocin-producing $E$. coli in the gnotobiotic mouse intestine (3). On the other hand, Ramaré et al. (7) showed that an antibacterial substance against Clostridium perfringens was produced by a Peptostreptococcus sp., but only in the digestive tract of gnotobiotic rodents and never in vitro. Fig. 2 shows that, such as in vitro (4), L. murinus exerts a potent antagonistic effect in vivo against $S$. sonnei (Fig. 2C) and to a lesser extent against $S$. Typhimurium (Fig. 2B) as revealed by inhibitory halos around the feces of Lactobacillus-associated animals. There was no halo against $S$. sonnei (Fig. 2A) and $S$. Typhimurium (data not shown) from germ-free animal feces.

Fig. 3 shows the L. murinus population levels in the contents of different portions of the intestinal tract of monoassociated mice. Higher populations of the bacteria were observed in the cecum and colon when compared to the small intestine where

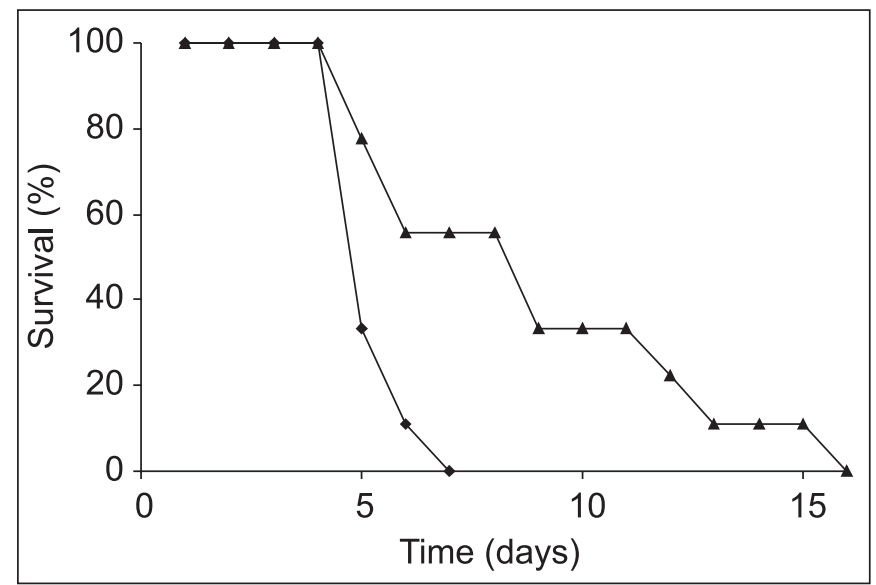

Figure 1. Survival of germ-free mice monoassociated $(\diamond)$ or not ( $\mathbf{\Delta})$ with Lactobacillus murinus during 10 days and then orally challenged with Salmonella Typhimurium. 

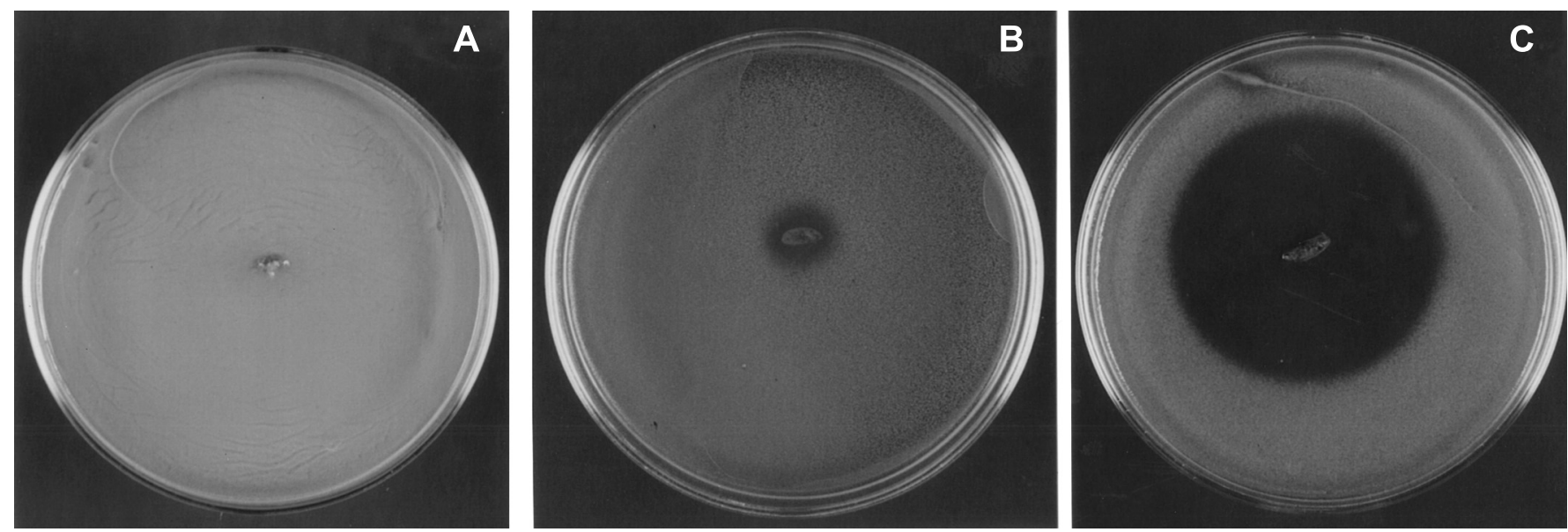

Figure 2. Ex vivo antagonistic tests against Shigella sonnei (A and C) or Salmonella Typhimurium (B) using feces from germfree (A) and Lactobacillus murinus-associated mice (B and C).

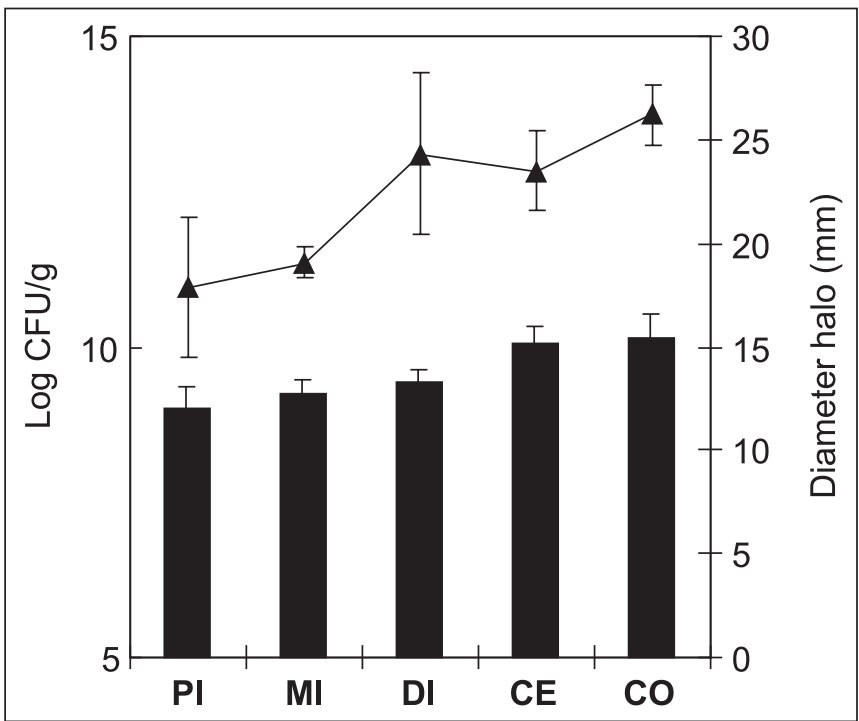

Figure 3. Mean population levels ( $\mathbf{\square})$ of Lactobacillus murinus in proximal (PI), median (MI) or distal (DI) small intestine, cecum $(\mathrm{CE})$ and colon $(\mathrm{CO})$ of mice and mean diameter $(\boldsymbol{\Delta})$ of inhibition halo against Salmonella Typhimurium for ex vivo antagonistic test in each anatomical portion.

peristalsis is faster. Diameters of the inhibitory halos increased along the intestine tract, following proportionally the L. murinus population levels in the respective intestinal portions. The frequency of intestinal contents showing inhibitory halo also increased along the digestive tract, being of $75 \%$ for the two first portions (proximal and median small intestines) and 100\% for the last three.

Concluding, the present study showed that L. murinus association in gnotobiotic mice delayed the death after an oral challenge with $S$. Typhimurium and that inhibitory diffusible compounds obtained in in vitro assays were also produced in vivo and may be responsible for this effect.

\section{RESUMO}

\section{Efeitos antagonista e protetor contra Salmonella enterica Sorovar Typhimurium por Lactobacillus murinus no trato digestivo de camundongos gnotobióticos}

No presente estudo, a produção de substâncias antagonistas por Lactobacillus murinus contra bactérias enteropatogênicas foi avaliada in vivo assim como um possível efeito protetor contra um desafio oral com Salmonella Typhimurium utilizando um modelo animal gnotobiótico. Um maior tempo médio de sobrevida $(\mathrm{P}<0,05)$ foi observado nos animais associados com L. murinus $(7,89 \pm 3,83$ dias) quando comparado com os controles (4,44 \pm 0,73 dias). Lactobacillus murinus exerceu um potente efeito antagonista in vivo contra $S$. sonnei e com menos intensidade contra $S$. Typhimurium como revelado pelos halos de inibição ao redor das fezes dos animais associados com $L$. murinus. Os diâmetros dos halos de inibição ao redor dos conteúdos intestinais aumentaram ao longo do trato digestivo, seguindo proporcionalmente os níveis populacionais de $L$. murinus nas respectivas porções intestinais. Concluindo, o presente estudo mostra que a associação com L. murinus em camundongos gnotobióticos retarda a morte após um desafio oral com $S$. Typhimurium e que compostos inibitórios difusíveis obtidos em ensaios in vitro foram também produzidos in vivo e podem ser responsáveis por este efeito.

Palavras-chave: antagonismo, Salmonella, Lactobacillus, camundongos gnotobióticos. 


\section{REFERENCES}

1. Berg, R.D. The indigenous gastrointestinal microflora. Trends Microbiol., 4:430-435, 1996.

2. Bernet, M.F.; Brassart, D.; Neeser, J.R.; Servin, A.L. Lactobacillus acidophilus LA1 binds to human intestinal cell lines and inhibits cell attachment and cell invasion by enterovirulent bacteria. Gut, 35:483489, 1994.

3. Duval-Iflah, Y.; Raibaud, P.; Rousseau, M. Antagonism among isogenic strains of Escherichia coli in the digestive tracts of gnotobiotic mice. Infect. Immun., 34:957-969, 1981.

4. Nardi, R.D.; Santos, A.R.M.; Carvalho, M.A.R.; Farias, L.M.; Benchetrit, L.C.; Nicoli, J.R. Antagonism against anaerobic and facultative bacteria through a diffusible inhibitory compound produced by a Lactobacillus sp. isolated from the rat fecal microbiota. Anaerobe, 5:409-411, 1999.
5. National Research Council. Guide for the care and use of laboratory animals. Institute of Laboratory Animal Resources, National Academy Press, Washington, D.C., 1996.

6. Neumann, E.; Oliveira, M.A.P.; Cabral, C.M.; Moura, L.N.; Nicoli, J.R.; Vieira, E.C.; Cara, D.C.; Podoprigora, G.I.; Vieira, L.Q. Monoassociation with Lactobacillus acidophilus UFV-H2B20 stimulates the immune defense mechanisms of germfree mice. Braz. J. Med. Biol. Res., 31:1565-1573, 1998.

7. Ramaré, F.; Nicoli, J.R.; Dabard, J.; Corring, T.; Ladiré, M.; Gueugneau, A.M.; Raibaud, P. Trypsin-dependent production of an antibacterial substance by a human Peptostreptococcus strain in gnotobiotic rats and in vitro. Appl. Environ. Microbiol., 59:28762883, 1993

8. Vandenbergh, P.A. Lactic acid bacteria, their metabolic products and interference with microbial growth. FEMS Microbiol. Rev., 12:221$238,1993$. 